\title{
The Influence of the CIRC and TTW Learning Model and Learning Motivation toward Grade 8 Students' Report Writing Skills at SMP Muhammadiyah Padang
}

\author{
Diana Kartika \\ Indonesian Language Education, Graduate Program, Bung Hatta University, Indonesia \\ Yetty Morelent \\ Indonesian Language Education, Graduate Program, Bung Hatta University, Indonesia
}

\begin{abstract}
The objectives of this research are (1) to find out whether the CIRC and TTW learning models significantly influence the students' ability to write reports at Muhammadiyah Junior High School Padang, (2) to explore whether the CIRC and TTW learning models have a significant influence on the highly motivated students' ability to write reports, (3) to analyze whether the CIRC and TTW learning models have a significant influence on the ability to write reports of the students with low motivation (4) to identify whether there is influence on the interaction between the use of CIRC type learning model and TTW and learning motivation toward their ability to write the report. This study was conducted within randomized controlgroup pretest-posttest experimental designs whose participants were Grade 8 students of Muhammadiyah Junior High School Padang. The instruments of data collection were report writing tests, questionnaires and interviews. The findings show that there is a significant influence of the use of CIRC and TTW type learning model with the students' motivation to learn the skills of writing reports. Secondly, there is a significant influence on the use of CIRC and TTW learning models on the highly motivated students' report writing skills. Thirdly, there is a significant influence on the use of CIRC and TTW learning models on the lowly motivated students' report writing skills. Finally, there is the interaction of the use of learning models of CIR and TTE types with their learning motivation on their report writing skills.
\end{abstract}

Index Terms—report writing skills, CIRC, TTW

\section{INTRODUCTION}

Indonesian lesson is one of the obligatory learning at all levels of education. Bahasa becomes one of the compulsory lessons for education in Indonesia as it is one of the identities of the Indonesian Nation. Therefore, Indonesian language has a strategic position in the school curriculum. The goal of Indonesian language learning in schools is not only for students to pass the exam, but the students must also be able to communicate by using good and correct Indonesian language. Therefore, the priority is given to the teaching of the four skills in order for the students to be able to gain knowledge and experience and to communicate well and correctly.

In a learning process, the main task of a teacher is to condition the environment in order to support the change of behavior for learners. The learning process needs to be done calmly and pleasantly; this of course requires the activity and creativity of teachers in creating a conducive environment. The learning process will work well if all learners are actively involved mentally, physically and socially in it. The main goal of a learning process is how to achieve the learning objectives well. Therefore, to achieve the intended purpose, the learning process must have a high quality, meaning that teachers need to utilize learning components as possible. The ability of teachers to implement the learning process depends on their accuracy in designing the lesson plans. With the right learning design, the teachhers are expected to be able to present the learning materials of Indonesian language well.

In addition to the factors derived from the students' lack of strong motivation to write, there are some other factors, namely the students' lack of vocabulary which results in their difficulty in composing words to create a report, and the lack of students' desire in reading, especially when given a long text. Another thing is the low average scores obtained by students on writing study reports. The results obtained from the Indonesian language teacher of Muhammadiyah Junior High School in Padang show that there are only 9 of 35 Grade 7 students whose average scores of daily assignments of semester I Year 2016-2017 and the test conducted on August 25, 2016 are above 76, the Pre-Determined Minimum Criteria of Standard Mastery (KKM).

Based on the problems that emerged above, related to the lack of learning models used by teachers and students' low motivation, the researchers intend to apply a learning model expected to be able to improve learning outcomes of 
Indonesian language, especially in enhancing the students' report writing skills. Therefore, the application of a new model of learning in reportvwriting, CIRC (Cooperative Integrated Reading and Composition) and TTW (Think-TalkWrite), is necessary to overcome the above problems. CIRC and TTW type of learning model is used as a solution in learning to write reports because it is an integrated cooperative learning composition of reading and writing, while the learning model of TTW is a learning model that can improve the sudents' ability of understanding and communication developed by way of thinking, speaking and writing. Therefore, the researchers want to combine the two models of learning CIRC and TTW in learning process of writing reports. This type of learning model of CIRC and TTW is expected to be able to help teachers to provide convenience to students when writing reports through group work and cooperative learning to find an idea that will be written in a report form.

It is based on the abovementioned facts that the researchers are interested in conducting research this research whose onjectives are as follows:

1. to find out whether the CIRC and TTW learning models significantly influence Grade 8 students' ability to write reports at Muhammadiyah Junior High School Padang;

2. to explore whether the CIRC and TTW learning models have a significant influence on the ability to write reports of Grade 8 students with high motivation;

3. to analyze whether the CIRC and TTW learning models have a significant influence on the ability to write reports of Grade 8 students with low motivation;

4. to identify whether there is influence on the interction between the use of CIRC type learning model and TTW and learning motivation toward Grade 8 students' ability to write the report at Muhammadiyah Junior High School Padang.

\section{REVIEW OF LITERATURE}

\section{A. Learning Model}

In learning, various problems are often experienced by teachers. To overcome various problems in learning, it is necessary to have learning models that are considered to help teachers in teaching and learning process. Models are designed to represent the real reality, although the model itself is not the reality of the real world. According to Suprijono (2011, p. 45), the model is defined as a form of accurate representation as an actual process that allows a person or group of people to try to act on that model. Another opinion is that the learning model is a pattern used as a guide in planning the learning in the classroom or tutorial (Suprijono, 2011, p. 46)

One of the learning models that can be used in the learning process of Indonesian language is Cooperative Integrated Reading and Composition commonly abbreviated as CIRC. Cooperative Integrated Reading and Composition (CIRC) learning is a method where students comprehensively learn by developing reading and writing skills. Cooperative Integrated Reading and Composition (CIRC) is a learning opportunity given to learners to work with other learners in structured tasks (Li \& Lam, 2015, p. 12).

This CIRC model is a tool in cooperative learning as the latest technique that teaches practical reading, writing that can be taught in Indonesian language lesson. Stevens et al (1991, p. 9) argue that this cycle of instruction has been applied to reading and writing instruction in the elementary grades, through the development of the Cooperative Integrated Reading and Composition (CIRC) program. So it can be concluded CIRC type learning model is a learning model that can provide an effective way of learning that can improve the ability of reading and writing activities.

Li \& Lam (2015, p. 20) highlight that CIRC comprises three major language activities: 1) Basal-related activities, 2) Direct instruction in reading comprehension, and 3) Integrated language arts/writing. All students are assigned to form teams composed of two pairs from two different groups. Each heterogeneous group is made up of a high ability pair and a low ability pair. In other words, while the pair is homogeneous in ability, the group is heterogeneous in ability. Different reading materials are assigned to the pairs according to their ability so that all members have an equal opportunity to succeed, irrespective of their ability. Though the pairs work on different materials, the pair with higher ability will help the low ability pair to learn. Scores will then be given to each member who has completed the three major languages activities. Each member's scores are counted towards the group's score each week. Rewards are given to the groups whose scores meet a required standard.

The think-talk-write learning model was developed by Huinker and Laughlin cited in Yamin \& Ansari (2008, p. 84) built through thinking, speaking and writing. This learning model can develop students' understanding and communication skills. Think-Talk-Write model flow begins with the involvement of students in thinking or dialogue with themselves after the reading process, then talk and share ideas with friends and then write the results of the discussion. This learning model is more effective if done in heterogeneous groups with 3-5 students. In this group all students are asked to read, make small notes, explain, hear and share ideas with friends and then express it through writing.

Meanwhile, the role of teachers in the TTW learning model according to Silver and Mith (Yamin \& Ansari, 2008, p. 84) are: 1) Asking questions and tasks that engage and challenge each student to think. 2) Carefully listen to student ideas. 3) Get students to express their ideas orally and in writing. 4) Decide what students are digging and carrying in the discussion. 5) Deciding when to inform, clarify problem issues, use models, guide and let students struggle with difficulties. 6) Monitor and assess student participation in the discussion and decide when and how to encourage each student to participate. So it can be concluded that this type of learning model TTW centered on students, the students in 
groups work together to discuss the material given, then the teacher is only as a facilitator to guide and monitor and motivate students.

\section{B. Motivation}

Motivation is one of the important determinants of learning. Yamin \& Ansari (2008, p. 157) cites the opinion of Mc. Donald defines motivation as a change of energy in a person (person) characterized by the emergence of feelings and reactions to achieve goals. This is supported by opinion Nasution (2002, p. 58) which describes that motivation is a force or energy that drives a person's behavior to move.

Furthermore, according to Yamin \& Ansari (2008, p. 158) motivation to learn is the power of psychic drive from within a person to be able to do learning activities and add skills, experience. Motivation encourages and leads the learning interest to achieve a goal. Students will earnestly study because they are motivated to seek achievement, gain positions in positions, become politicians, and solve problems. Based on some opinions that have been described, it can be concluded that motivation is a force or energy that encourages a person to do something to achieve goals both positive and negative goals.

Motivated people can be seen from the characteristics that exist in the person. The characteristics of people motivated, among others, are not easily desperate in completing a job, always feel like to make his achievements are increasing. Sardiman (2011, p. 83) suggests the motivation in each person has the following characteristics: (1) Diligent to face the task; (2) Ductile facing difficulties; (3) Showing interest in various problems; (4) Preferably working independently; (5) Get bored with routine tasks; (6) Can defend his opinion; (7) It is not easy to let go of what is believed; (8) Glad to find and solve problem questions.

Based on the above characteristics it can be concluded that the motivated student's indicator is tenacious and diligent in completing the task, showing interest, always paying attention, and having the spirit and the desire to learn to get good learning outcomes.

Haryanti (2007, p. 11) explains that learning outcomes are the object of evaluation of the learning process. Learning outcomes can also be interpreted as a result of the teaching process of teachers and learners learners. Learning outcomes are often used as a measure to find out how far a person has mastered the material already taught. Learning outcomes are a change in learners' behavior.

Learning outcomes of learners can be in the form of assessment in the form of numbers as an index of achievement to determine the success of learners. The results of the assessment provide feedback information, both learners and teachers. Weakness in learning outcomes is interpreted as a lack of achievement of teaching objectives. In other words, there are a number of objectives that may not be achieved or miss the previously planned targets (Hamalik, 2003, p. 234). Thus it can be concluded that learning outcomes are scores obtained from a change process toward behavior change and attitude changes that are permanent and durable and formed as a result of interaction with the environment.

Bloom's Lessons cited by Sudjana (2008, p. 22) describe some of the aspects assessed for the classification of learning outcomes that broadly divide it into three domains, namely; 1) the cognitive domain is the domain that is related to the memory or the introduction of knowledge and information, and the development of intellectual skills, 2) the affective aspect is dealing with attitudes and values, the type of affective learning outcomes appear in learners in various behaviors such as attention to the lessons, discipline, learning motivation, respect for teachers and classmates, study habits, and social relationships, 3) psychomotor domains ie Psychomotor domains associated with motor skills, manipulation of objects or activities that require neural coordination and coordination of the body.

\section{Writing}

In Big Indonesian Dictionary (2008: 1098) writing is defined as (1) making letters (numbers, etc); (2) giving birth to thoughts or feelings (such as composing, making letters) with writing. Sumardjo (2007, p. 75) says that writing is a process of giving birth to writing that contains ideas. Many do spontaneously, but also repeatedly make corrections and rewrite them.

Tarigan (2008, pp. 3-4) adds that writing is an activity that is productive and expressive. In writing activities, a writer must be skilled at utilizing graphology, language structure, and vocabulary. Writing skills will not come automatically but must go through practice. Furthermore, Tarigan (2008, p. 22) argues that writing is to derive or represent graphic representations depicting a language understood by a person, so that others can read the graphic symbols if they understand the language and graphic representation. So, it can be interpreted that writing is the process of making letters that contain ideas and derived from thoughts or feelings that are then poured into the form of writing.

Hartig cited in Tarigan (2008, p. 25) mentions the Seven Writing Purposes, firstly the purpose of assignment (assigment purpose). The purpose of this assignment actually has no purpose at all. The author writes something because it is assigned, not of its own accord (eg the students assigned to summarize the book, the secretary assigned to make the report). Second, the purpose of altruistic (altruistic purpose) is to please the readers, want to help readers understand, appreciate the feelings and reasoning want to make life readers easier and more fun with his work. One can not write properly if he believes, consciously or unconsciously that the reader or the connoisseur of his work is the "enemy" or "enemy". The purpose of altruistic is the key to the readability of something written. Third, the purpose of persuasive (persuasive purpose) is writing that aims to convince the readers of the truth of the ideas expressed. Fourth, the purpose of informational purpose information (informational purpose) writing that aims to memeberikan 
information or information / light to the readers. Fifth, the purpose of self-awareness (self express purpose) is for the author's self-statement to the readers. Sixth, the creative purpose of this goal is closely related to the purpose of selfrevelation, but the "creative will" here outweighs the self-assertion, and engages itself with the desire to attain artistic norms, or ideal arts, the arts of art. Writings that aim to achieve artistic values, artistic values. Seventh, the purpose of problem-solving (problem-solving purpose) is to solve problems encountered. The author wants to explain, clarify, explore and examine carefully his own thoughts and ideas in order to be understood and accepted by the reader.

The main function of writing is considered as an indirect means of communication. Writing is very important for education because it makes it easy for students to think, that is critical thinking, make it easier for us to feel and enjoy relationships, deepen our responsiveness or perceptions, solve problems we face, arrange sequences for experience, writing can also help us explain mind- our minds (Tarigan, 2008, pp. 22-23).

So, writing activity is very much a benefit that is to improve thinking power, add references, and also write useful psychological, cultural, economic, and intellectual.

\section{Writing Report}

Hasnun (2004, p. 49) explained that the report originated from the Latin reportare, bringing back written documents compiled as a result of procedures to explain the information. A formal (formal details of a matter) notice of facts, records or results of something in a systematic way. Reports are everything that is reported. Another thing is presented by Keraf $(2004$, p. 324) who argues that the report is a way of communication the author conveys information to a person or a body because of the responsibilities imposed on it. While Widyamartaya $(2005$, p. 7$)$ which states that the writing of the report is the delivery of information that is factual about something from one party to another party. In other words, report writing involves three things, namely (1) what is reported, (2) who is reporting, and (3) to whom the report is submitted. From various notions about the report can be concluded that the report merupkan a message or information submitted to a person, government, good institutions from one to another that provides information based on fact.

Keraf (2004, p. 327) describes the report has several forms, namely: a report in the form of a form field, which is a routine report, and often in the form of numbers. Although the figures are not writings, they should be done with care; report in the form of a letter, that is a report that is not much different from ordinary letter, unless there is a subject to be conveyed in order to be known by the recipient of the report. When the author decides to use a letter form for his report, personal tones and approaches play an important role, as do the other letters, but they are much longer than ordinary letters; memorandum-shaped reports, memorandum-shaped reports (suggestions, notes, short notes) are similar to lettershaped reports, but are usually shorter. A memorandum-shaped report is often used for a brief report in sections of an organization, or between superiors and subordinates in an employment relationship; progress reports and state reports. Progress reports are principally different from state reports; periodic reports or periodic reports. Such reports are made within a certain timeframe; a laboratory report, one of the laboratory reports is to convey the results of experiments or activities performed in the laboratory. Therefore, this report often contains only experiments that have been done; formal and semiformal reports, formal reports are reports that meet certain requirements, for example there should be a title page, usually a submission letter, always have a table of contents, there is an overview to start the report, there are introductions, conclusions and suggestions given their own titles, the contents of the report consist of titles with different levels, the tone used is the official tone, if necessary the report is accompanied also tables and figures, whether embedded in the text of the report, or attachments, formal reports are usually specially documented.

\section{RESEARCH METHODOLOGY}

This study was categorized into experimental research using quasi experimental method. Experimental research reveals the relationship between two or more variables or search for the influence of a variable on other variables (Sudjana and Ibrahim 2004, p.19). In addition, Sugiyono (2009, p. 107) argued experimental research can be interpreted as a research method used to find the effect of certain treatment against others in a controlled condition. In the experiment there are two variables that become the main concern, namely the independent variable and the dependent variable. The purpose of this research is to obtain empirical data about the relationship between X1 (CIRC and TTW type learning model) and X2 (learning motivation) with Y (writing skill report). The purpose of this research is to find out whether there is influence of CIRC and TTW type learning model (X1) on Grade 8 students' writing skill report (Y) at SMP Muhammadiyah Padang. In addition, the research aims to see whether there is influence of learning motivation (X2) on Grade 8 students' writing skill report (Y) and interaction between CIRC and TTW type learning model (X1) and learning motivation (X2).

\section{A. Setting}

This research was conducted at SMP Muhammadiyah Padang, located at Simpang Haru, Padang, West Sumatra, Indonesia.

\section{B. Participants}


There are three parallel classes in Grade 8, two of which, Class 1 and Class 3, were selected for this resesearch. The research involved 33 students of Grade 8 from Class 1 used as the experimental group and 32 students of Grade 8 from Class 3 use as a control group.

\section{Instruments}

The research instruments for this study are closed questionnaires and a test of report writing. The questionnaire of learning motivation used a likert-type 5-point scale: SL (always), SR (often), KD (sometimes), JR (rare), TP (never). The positive items were given points $5,4,3,2,1$ and negative items were given points 1, 2, 3, 4, 5 .

The form of the instrument used in this study is a questionnaire on motivation to learn report witings and a report writing test. The test of this research instrument is internal validity test. Internal validity includes content validity and construction validity. The validity of the constructs carried out by expert judment, namely to seek expert opinion as suggested by Sugiono (2009, p. 172). To determine the validity of the instrument, the product moment correlation formula were used. The result of rxy calculation on the critical table $r$ product moment with $5 \%$ significance. If rxy> rtabel then that aspect is valid. Instrument reliability testing can be done externally or internally. Externally the test can be done by test-retest (stability), equivalent, and both combined while internally the reliability of the instrument can be tested by analyzing the consistency of the items on the instrument with a particular technique (Sugiyono, 2009: 183). The reliability of this study instrument is calculated by the alpha cronbach formula presented by Kasmadi and Sunariah (2013: 70). The result of $r$ calculation in table rhitung with 5\% significance. The criterion of reliability if rhitung > rtabel then the aspect is reliable.

TABEL 3.1

RELIABILITY STATISTICS

\begin{tabular}{|l|l|}
\hline Cronbach's Alpha & N of Items \\
\hline .893 & 20 \\
\hline
\end{tabular}

The test results seen in Table 3.1 shows that the value of alpha cronbach is 0.893 . this means a reliable questionnaire because in the study obtained alpha> 0.05 .

Data collection techniques in this study were conducted by providing test report writing skills through preexperimental, experimental, post-experimental stage, data analysis, and preparation of research results.

The data analysis begins with (1) the recording of the mean postest score of the students' writing skills on the two classes, (2) comparing the postest score of the final report writing skill on each class, (3) examining the difference in postest class score taught by the learning model type CIRC and TTW and convensonally for groups of students who have high and low learning motivation, as well as to test the hypothesis, (4) calculate the interaction of the use of CIRC and TTW type learning models with learning motivation to report writing skills, as well as to test the hypothesis.

\section{RESUlt AND DisCUSSION OF RESEARCH}

This section presents the cotrol group's result of the posttest of report writing skills intended to see their writing skill progress in which no media were used in the learning process. There were 33 students of the control group who participated in this posttest, the result of which showed that the highwst score was 84 and the lowest was 62 .

In addition, the Posttest of the report writing skills involved 33 students of the experimental group and was conducted to see whether result could show the good progress of the expereimental group of the students who were taught using CIRC and TTW type learning model.

The report writing skills were taught by using audio-visual media to the students who were highly motivated and generally the result showed a score range of $72-84$ with the lowest score of 72 and the highest score of 84 . With SPSS 17, it was found the mean score of 72.36, the mode score of 72, the median of 71.00 and its standard deviation of 5.361 .

Furthermore, report writing skills were conventionally taught to the students who are also higly motivated. The result showers a score range of 60 - 79 with the lowest score of 60, the highest score of 79 . Their report writing skills had the mean score of 67,39 , the mode score of $70 \mathrm{a}$, the median score of $70 \mathrm{a}$, the variance of 13.166 and standard deviation of 5.875

A similar treatment, namely the report writing skills, was taught by using CIRC and TTW type learning model to the students who were lowly motivated and generally the result showed a score range of 62-76 with a low score of 62 and a high score of 76. Their report writing skills had the mean score of 70, 02, the mode score of 78, the median score of 69 , and standard deviation of 4.321 .

The report writing skills were also conventionally taught to the lowly motivated students. The result showed a score range of 55-62 with the lowest score of 55 and the highest score of 62. With SPSS 17, it was found that their report writing skills showed the mean score of 67,00 , the mode score of 68 , the medin score of 69,00 , and the standar deviation of 4.239 .

As normality tests check if a population significantly differs from a normal distribution, the first step in this research was conducting the normality tests toward the control and experimental groups' report writing tests. The result is presented in the table below: 
TABLE 4.1.

THE SUMMARY OF THE RESULT OF NORMALITY TESTS OF THE CONTROL AND EXPERIMENTAL GROUPS' REPORT WRITING SKILLS

\begin{tabular}{|l|l|l|l|}
\hline No & Data & Asymp. Sig (2- tailed) & Information \\
\hline 1 & Pretest Control Grop & 0,324 & Asymp. Sig (2-tailed) $>0,05=$ normal \\
\hline 2 & Posttest Control Group & 0.296 & Asymp. Sig (2-tailed) $>0,05=$ normal \\
\hline 3 & Pretest Experimental Grop & 0.452 & Asymp. Sig (2-tailed) $>0,05=$ normal \\
\hline 4 & Posttest Experimental Group & 0.254 & Asymp. Sig (2-tailed) $>0,05=$ normal \\
\hline
\end{tabular}

SPSS 17 was used to do the normality tests. The result shows that both the experimental and control groups' data of the pretest and posttest were normally distributed as both all of the tests have a p-value greater than 0.05 , which indicates normal distribution of data. Therefore, the data are eligible for parametric statistical tests.

As the data were normally distributed, the next step wat to conduct the homogeneity test. As the $\mathrm{p}$ value of the pretest (0.547) and the posttest (0.653) were greater than 0.05 , which indicates homogeneous distribution of data. Therefore, the data are eligible for parametric statistical tests.

TABLE 4.2.

THE SUMmaRY OF HOMOGENEITY TEST RESUlts OF VARIANT DATA OF REPORTS WRITING SKILLS

\begin{tabular}{|l|l|l|l|l|}
\hline No & Data & Levene Statistics & P & Note \\
\hline 1 & Pretest & 0.026 & 0.547 & Sig. $0.547>0,05=$ homogeneous \\
\hline 2 & Postest & 0.276 & 0.653 & Sig. $0.653>0,05=$ homogenous \\
\hline
\end{tabular}

The first hypothesis test, the null hypothesis (H0), in this research is whether the CIRC and TTW learning models do not significantly influence Grade 8 students' ability to write reports at Muhammadiyah Junior High School Padang. In addition, the second hypothesis (H1) was to see whether the CIRC and TTW learning models significantly influence Grade 8 students' ability to write reports at Muhammadiyah Junior High School Padang. The t-test calculation was performed with SPSS 17.0. to see whether data requirements are significant if $\mathrm{p}$ is less than 0.050 .

TABLE 4.3.

THE SUMMARY OF T-TEST RESULTS BETWEEN LEARNING CONTROL GROUP AND EXPERIMENTAL CLASS MOTIVATION.

\begin{tabular}{|l|l|l|l|l|}
\hline Data & th & $\mathrm{Db}$ & $\mathrm{P}$ & Ket \\
\hline Postest Experiment and Control & 1.386 & 63 & 0.000 & $0<0.05=$ not significant \\
\hline
\end{tabular}

From the table it can be seen that $\mathrm{F}$ arithmetic is 1.386 with $\mathrm{db} 63$ obtained $\mathrm{p}$ value 0.000 . The $\mathrm{p}$ value is greater than 0.050. Thus, the t-test results show there is a significant influence between control group learning motivation and experimental group.

The second hypothesis test the null hypothesis (H0), in this research is "There is no effect of CIRC and TTW type learning model on Grade 8 highly motivated students' ability to write report reports at Muhammadiyah Junior High School Padang Padang while the second hypothesis (H1) is that "There is an effect of CIRC and TTW type learning model on Grade 8 highly motivated students' ability to write report reports at Muhammadiyah Junior High School Padang. The t-test calculation was performed with SPSS 17.0. and data requirements are significant if $\mathrm{p}$ is less than 0.050 .

TABLE 4.4

SUMMARY OF T-TEST RESULTS BETWEEN THE POSTEST GROUP WRITING SKILLS OF THE EXPERIMENTAL GROUP AND CONTROL GROUP REPORTS

\begin{tabular}{|l|l|l|l|l|}
\hline Data & th & $\mathrm{Db}$ & $\mathrm{P}$ & Ket \\
\hline Postest Experimen and Control & 3.985 & 63 & 0.000 & $\mathrm{P}<0.05=$ significant \\
\hline
\end{tabular}

The Postests of the control group and experimental group show t-value of 3.985, df 63, $\mathrm{P} 0.000$, which is $<0.05=$ significant. From Table 4.4, the p value is less than 0.050 (p: $0.000<0.05$ ). Thus, the t-test results show that there is a significant influence on the control group being taught without using the CIRC and TTW type learning models and the experimental group taught using the CIRC and TTW type learning models.

The third hypothesis test in this study, the null hypothesis (H0), is that the CIRC and TTW learning models have no significant influence on Grade 8 lowly motivated students' ability to write reports at Muhammadiyah Junior High School Padang while the second hypothesis (H1) is that the CIRC and TTW learning models have a significant influence on Grade 8 lowly motivated students' ability to write reports at Muhammadiyah Junior High School Padang.

Two-way anova tests were performed with SPSS 17.00. and the result shows f value of 23,49. While F-table with df of numerator 1 and df denominator 63 at the level of $\alpha=0.05$ is known at 4.34. Based on this result, it can be concluded that if $\mathrm{Fh}>\mathrm{Ft}$ at the 0.05 level with dk numerator 1 and dk denominator 63, the conclusion is there is interaction.

The fourth hypothesis test, the null hypothesis (H0), in this research is "There is no interaction between the learning model of CIRC and TTW type and Grade 8 student's learning motivation and their ability to write reports at Muhammadiyah Junior High School Padang. In addition, the second hypothesis (H1) was" There is an interaction between the learning model of CIRC and TTW type and Grade 8 student's learning motivation and their ability to write reports at Muhammadiyah Junior High School Padang. 
Two-way anova tests were performed with SPSS 17.00. and the result shows f value of 21,65. While F-table with df of numerator 1 and df denominator 63 at the level of $\alpha=0.05$ is known at 3.93. Based on this result, it can be concluded that if $\mathrm{Fh}>\mathrm{Ft}$ at the 0.05 level with $\mathrm{dk}$ numerator 1 and $\mathrm{dk}$ denominator 63 , the conclusion is there is interaction.

\section{CONCLUSION}

Based on the results of the analysis that has been previously presented, it can be concluded that there is a significant influence of the use of CIRC and TTW type learning models with learning motivation toward Grade 8 students' writing skill at Muhammadiyah Junior High School Padang. Secondly, there is a significant influence on the use of CIRC and TTW type learning models on the highly motivated students'writing skills. Thirdly, there is also a significant influence on the use of CIRC and TTW type learning models on the stdents' lowly motivated writing skills. Fourth, there is the interaction of the use of learning models of CIR and TTE types with students' learning motivation on the Grade 8 students' writing skills at Muhammadiyah Junior High School Padang.

\section{REFERENCES}

[1] Arsyad, A. (2013). Media Pembelajaran. Jakarta : Raja Grafindo Persada.

[2] Bahasa, P. (2008). Kamus Besar Bahasa Indonesia. Jakarta: Gramedia Pustakan Utama.

[3] Hamalik, O. (2003). Pendidikan guru: berdasarkan pendekatan kompetensi. Jakarta: Bumi Aksara.

[4] Haryanti, D. (2007). Pergeseran Kategori Nomina Dan Verba Dalam Linguistics Across Cultures Dan Linguistik Di Pelbagai Budaya. Linguistik Indonesia, 25(1), 1-17.

[5] Hasnun. (2004). Pedoman dan Petunjuk Praktis Karya Tulis. Yogyakarta : Absolut.

[6] Kasmadi, \& Sunariah, N. S. (2013). Panduan Modern Penelitian Kuantitatif. Bandung: Alfabeta.

[7] Keraf, G. (2004). Komposisi: Sebuah Pengantar Kemahiran Bahasa. Flores : Nusa Indah.

[8] Li, M. P., \& Lam, B. H. (2015, November 16). The Hong Kong Institute of Education. Diambil kembali dari Welcome to Active Classroom: http://www.eduhk.hk/aclass/.

[9] Nasution. (2002). Metode Research: Penelitian Ilmiah. Jakarta: PT. Bumi Aksara.

[10] Nurgiyantoro, B. (2007). Teori Pengkajian Fiksi. Yogyakarta: Gadjah Mada University Press.

[11] PP-19-2005. (2005, November 16). Peraturan.go.id. Diambil kembali dari Peraturan Pemerintah Nomor 19 Tahun 2005 : http://www.peraturan.go.id/pp/nomor-19-tahun-2005-11e44c4eb763e8e09edc313231363039.html.

[12] Riyanto, A. (1982). Peranan Media Audio Visual dalam Pendidikan. Yogyakarta: Kanisius.

[13] Safari. (2003). Evaluasi Pembelajaran. Jakarta: Depertamen Pendidikan Nasional Direktorat Jendral Pendidikan Dasar dan Menengah Direktorat Tenaga Kependidikan.

[14] Sardiman, A. (2011). Interaksi dan Motivasi Belajar Mengajar. Jakarta: Rajawali Press.

[15] Slameto. (2003). Belajar dan Faktor-Faktor yang Mempengaruhinya. Jakarta: Rineka Cipta.

[16] Stevens, J. R. (1991). The Effects of Cooperative Learning and Direct Instruction in Reading Comprehension Strategies on Main Idea Identification. Journal of Educational Psychology, 83(1), 8-16.

[17] Sudjana, N. (2008). Penilaian Hasil Proses Belajar Mengajar. Bandung: PT Remaja Rosdakarya.

[18] Sugiono. (2009). Metode Penelitian Pendidikan. Bandung: Alfabeta.

[19] Sumardjo, J. (2007). Catatan Kecil Tentang Menulis laporan. Yogyakarta : Pustaka Pelajar.

[20] Suprijono, A. (2011). Model-Model Pembelajaran. Jakarta:: Gramedia Pustaka Jaya.

[21] Tarigan, H. G. (2008). Membaca Sebagai Suatu Keterampilan Berbahasa. Bandung: Angkasa.

[22] Thahar, H. E. (2008). Menulis Kreatif Panduan bagi Pemula. Padang: Universitas Negeri Padang Press.

[23] Widyamartaya, A. (2005). Kiat Menulis Deskripsi dan Narasi. Yogyakarta: Pustaka Widyatama.

[24] Yamin, M., \& Ansari, B. I. (2008). Taktik mengembangkan kekmampuan individual siswa. Jakarta : Gaung Persada Press.

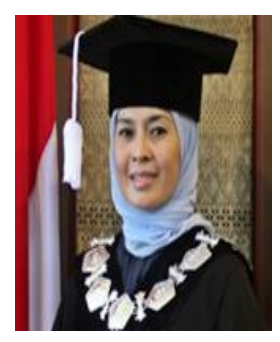

Diana Kartika was born in Palembang, on 15 April 1967. She is a lecturer of Japanese Literature, Faculty of Cultural Studies, and the M.Ed program in Indonesian Language Education, Bung Hatta University, Padang, Indonesia. She studied in Bung Hatta University for her BA in East Asia Literature, and in Jakarta State University for her MA and PhD in Language Education. She presented her papers in national and international conferences in Indonesia and abroad.

Dr. Kartika is the vice rector for students' affairs and was the department head of Japanese literature in Bung Hatta University, Padang, Indonesia.

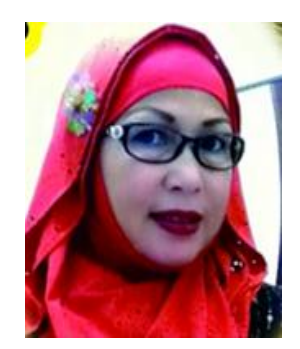

Yetty Morelent, M.Hum was born in Pekanbaru on 10 April 1963. She is a lecturer of Indonesian Literature, Faculty of Cultural Studies, and the M.Ed. program in Indonesian Education, Bung Hatta University, Padang, Indonesia. She studied in Bung Hatta University for her BA in Indonesian Education, and in Padjadjaran University for her MA in Linguistics and $\mathrm{PhD}$ in Language Education in Education University, Bandung Indonesia.

Dr. Morelent is the department head of the M.Ed. program in Indonesian Language Education, Bung Hatta University, Padang, Indonesia. 